University of Nebraska - Lincoln

DigitalCommons@University of Nebraska - Lincoln

$11-2009$

\title{
Selection for Drought Tolerance in Dry Bean Derived from the Mesoamerican Gene Pool in Western Nebraska
}

\author{
Carlos A. Urrea \\ University of Nebraska-Lincoln, currea2@unl.edu \\ C. Dean Yonts \\ University of Nebraska-Lincoln, cyonts1@unl.edu \\ Drew J. Lyon \\ University of Nebraska-Lincoln, drew.lyon@wsu.edu \\ Ann E. Koehler
}

Follow this and additional works at: https://digitalcommons.unl.edu/panhandleresext

Urrea, Carlos A.; Yonts, C. Dean; Lyon, Drew J.; and Koehler, Ann E., "Selection for Drought Tolerance in Dry Bean Derived from the Mesoamerican Gene Pool in Western Nebraska" (2009). Panhandle Research and Extension Center. 108.

https://digitalcommons.unl.edu/panhandleresext/108

This Article is brought to you for free and open access by the Agricultural Research Division of IANR at DigitalCommons@University of Nebraska - Lincoln. It has been accepted for inclusion in Panhandle Research and Extension Center by an authorized administrator of DigitalCommons@University of Nebraska - Lincoln. 


\title{
Selection for Drought Tolerance in Dry Bean Derived from the Mesoamerican Gene Pool in Western Nebraska
}

\author{
Carlos A. Urrea,^ C. Dean Yonts, Drew J. Lyon, and Ann E. Koehler
}

\begin{abstract}
Dry bean (Phaseolus vulgaris L.) is highly susceptible to drought stress, and drought affects $60 \%$ of global bean production. We evaluated elite exotic dry bean germplasm derived from the Mesoamerican gene pool for drought tolerance, yield, and adaptation to western Nebraska during 2006 and 2007 at three research sites. Seven tropical lines were evaluated with two great northern cultivars (Matterhorn and Beryl$\mathrm{R}$ ) and one pinto cultivar (Bill-Z) serving as checks. Adjacent nonstressed (NS) and droughtstressed (DS) blocks were evaluated. Within each block, the selected lines were assigned to experimental units using a randomized complete block design with four replications at each location. On average, yield was 60\% less, 100-seed weight was $19.2 \%$ lower, and maturity occurred $4 \mathrm{~d}$ earlier under DS than under NS conditions. Beryl-R, SER 22, and Matterhorn had the greatest average yield under both NS (3564, 3347, and $3440 \mathrm{~kg} \mathrm{ha}^{-1}$, respectively) and DS (1701, 1773, and $1584 \mathrm{~kg} \mathrm{ha}^{-1}$, respectively). These genotypes were also the most drought tolerant based on the drought susceptibility index $(0.9$, 0.8 , and 0.9 , respectively) and geometric mean (2462, 2436, and 2335, respectively). Based on these results, Matterhorn, Beryl-R, and SER 22 show the most promise for use in breeding for drought tolerance.
\end{abstract}

Univ. of Nebraska, Panhandle Research \& Extension Center, 4502 Ave. I, Scottsbluff, NE 69361. Received 8 Dec. 2008. *Corresponding author(currea2@unl.edu).

Abbreviations: DII, drought intensity index; DS, drought-stressed; DSI, drought susceptibility index; GM, geometric mean; NS, nonstressed.

$\mathrm{D}$ RY BEAN (Phaseolus vulgaris L.), also known as common bean, is the most important food legume in the world, representing $50 \%$ of the grain legumes consumed worldwide. In 2005, dry bean and snap bean were grown on 27.7 million ha in 148 countries, producing 25.6 million Mg (FAOSTAT, 2006). United States dry bean production supplies both domestic (canning and dry) and export markets, the latter valued at \$272 million during the 2007-2008 crop year (USDA-ERS, 2008).

The central and northern Great Plains (North Dakota, Nebraska, Colorado, and Wyoming) account for more than 56\% of the total dry bean production in the United States. Nebraska ranks third in U.S. dry edible bean production (USDA-ERS, 2008 ) and, in 2008, 132,150 Mg of dry edible bean (11\% of the U.S. crop) was produced on 54,634 ha. Nebraska production was $50 \%$ great northern (86\% of the U.S. crop), 39\% pinto (second in the United States), and 11\% light red kidneys (first in the United States) (USDA-ERS, 2008). Nebraska dry bean production is scattered throughout 26 western counties, particularly the 11 counties in the Nebraska Panhandle.

Drought is the most important abiotic factor affecting yield in dry bean and is a normal, though unpredictable occurrence in the Great Plains. Drought reduces yield, quality, and often the market value of dry bean. The severity of yield reduction depends on the timing, extent, and duration of drought stress (Singh,

Published in Crop Sci. 49:2005-2010 (2009).

doi: 10.2135/cropsci2008.12.0694

(C) Crop Science Society of America

677 S. Segoe Rd., Madison, WI 53711 USA

All rights reserved. No part of this periodical may be reproduced or transmitted in any form or by any means, electronic or mechanical, including photocopying, recording, or any information storage and retrieval system, without permission in writing from the publisher. Permission for printing and for reprinting the material contained herein has been obtained by the publisher. 
1995). Furthermore, the presence of other stressors (e.g., high temperature, disease, and poor soils) can amplify the impact of drought (Ramirez-Vallejo and Kelly, 1998).

In the Great Plains, the dry bean industry developed using irrigation to mitigate such climatic effects. Irrigation provides greater profitability and income stability than dryland farming. However in recent years, groundwater decline due to overuse has resulted in pumping restrictions in many areas of Nebraska. In addition, multiyear drought has reduced water storage in reservoirs, leading to allocations for surface irrigators. For example, in 2006, Seminoe and Pathfinder reservoirs in the North Platte River System held only 85 and 33\% of their 30-yr average, respectively (Yonts, 2005). Such ground and surface water restrictions and allocations have required a shift to limited irrigation or a return to dryland crop production in some areas of the Great Plains (Census of Agriculture, 1992, 1997, and 2002). The 9-yr drought across the Intermountain West and Great Plains has magnified the resulting yield losses.

In addition to water restrictions, growers' irrigation management decisions are increasingly influenced by the costs associated with irrigation and other aspects of dry bean production. Fuel, labor, and equipment costs accounted for $14 \%$ of variable costs of dry bean production in 2004 (Selley et al., 2004) and fuel costs have become highly variable and unpredictable in recent years.

Drought effects, whether due to climate and/or changing agronomic practices, are not a new problem for dry bean production areas. Breeding for drought tolerance has resulted in dramatic yield improvements in crops such as tomato (Solanum lycopersicum var. lycopersicum L.), cowpea (Vigna unguiculata L.), and maize (Zea mays L.), but less so in common bean (Singh, 2001). Improving drought tolerance of common bean has been slow because of unreliable techniques for measuring plant responses, phenological plasticity, and the inability to create repeatable screening environments (Ramirez-Vallejo and Kelly, 1998). Early genetic studies found that drought tolerance, measured as yield, was an additive trait that interacted with the environment (White et al., 1994b). A wide range of heritabilities (0.09-0.80) have been reported depending on environmental conditions and market class of the bean lines evaluated (Schneider et al., 1997b; Singh, 1995).

There has been considerable research evaluating various aspects of drought tolerance in dry bean in other countries (e.g., Acosta-Gallegos and Adams, 1991; White and Singh, 1991; Acosta-Gallegos and White, 1995; Singh, 1995; Schneider et al., 1997a; Terán and Singh, 2002a; Shenkut and Brick, 2003). In the United States, most studies have been conducted in Idaho (Lema et al., 2006; Muñoz-Perea et al., 2006; Singh, 2007) and Michigan (Acosta-Gallegos and Adams, 1991; Schneider et al., 1997a; Ramirez-Vallejo and Kelly, 1998). As drought responses may differ among regions (Acosta-Gallegos and Adams, 1991), similar efforts are needed in the Great Plains. Such variable responses to drought stress may result from differences in drought characteristics among regions (e.g., timing, frequency, duration, intensity, phenological stage affected, predictability), environmental considerations (e.g., photoperiod length, soil type), and/or the impact of other local factors that limit production (e.g., diseases and insects) (White and Singh, 1991).

Dry bean is popular because it requires less water to produce than many other crops grown in this region, which enhances producer management options for maintaining profitability. However, given the prevalence of drought and irrigation restrictions, it is critical that we identify high-yielding, drought-tolerant dry bean lines to reduce dependence on irrigation water, lower costs of production, and increase profit margins. Therefore, we conducted this study to evaluate elite exotic dry bean germplasm derived from the Mesoamerican gene pool for drought tolerance, yield, and adaptation to western Nebraska.

\section{MATERIALS AND METHODS Locations}

This study was conducted during 2006 and 2007 at three research sites associated with the University of Nebraska. Soil at the Scottsbluff site $\left(41^{\circ} 53.6^{\prime} \mathrm{N}, 103^{\circ} 40.7^{\prime} \mathrm{W}, 1200 \mathrm{~m}\right.$ elevation) is a Tripp very fine sandy loam (coarse-silty, mixed, superactive, mesic Aridic Haplustoll). Soil at the Mitchell site (41 ${ }^{\circ} 56.6^{\prime}$ $\mathrm{N}, 103^{\circ} 41.9^{\prime} \mathrm{W}, 1240 \mathrm{~m}$ elevation) is a silt loam (Typic Ustorthent). Soil at the Sidney site $\left(41^{\circ} 12^{\prime} \mathrm{N}, 103^{\circ} 0^{\prime} \mathrm{W}, 1315 \mathrm{~m}\right.$ elevation) is a Keith silt loam (fine-silty, mixed, superactive, mesic Aridic Argiustoll).

\section{Germplasm}

In 2005, 110 exotic dry bean genotypes were tested under drought conditions in a replicated trial at Mitchell, NE. These genotypes included five cultivars from the race Durango that were developed by the Mexican National Program (J.A. Acosta-Gallegos, personal communication, 2005), two black cultivars from Michigan (J.D. Kelly, personal communication, 2005), and 103 drought-tolerant bean genotypes (blacks, reds, and pinks) from the Mesoamerican gene pool that were developed at the International Center for Tropical Agriculture (CIAT, S. Beebe, personal communication, 2005). During this trial, irrigation was discontinued after flowering and the plots received only $76 \mathrm{~mm}$ of precipitation between flowering and harvest. The seven top yielding genotypes were selected for additional testing and seed was increased in winter nurseries at the Tropical Agriculture Research Station near Isabela, PR, and Blenheim, New Zealand, during the 2005-2006 and 2006-2007 growing seasons, respectively.

We further evaluated these tropical genotypes (SEC 10, SEN 3, SEN 20, SEN 21, SER 10, SER 22, and SER 26) (Table 1) in the current study with two great northern cultivars (Matterhorn [Kelly et al., 1999] and Beryl-R) and one pinto cultivar (Bill-Z) (Wood et al., 1989) serving as checks. Many of these genotypes were derived from crosses between Durango and Mesoamerican gene pools (S. Beebe, personal communication, 2005). 


\section{Experimental Design}

We evaluated the impact of drought using adjacent nonstressed (NS) and droughtstressed (DS) blocks as described by Terán and Singh (2002a). A buffer of $7.6 \mathrm{~m}$ of a drought-resistant cultivar was planted between adjacent blocks to reduce the lateral movement of water from the NS to the DS plots. Within each block, the selected genotypes were assigned to experimental units using a randomized complete block design with four replications at each location. Each plot consisted of four 7.6-m rows spaced $0.6 \mathrm{~m}$ apart. Targeted plant density was 200,000 plants ha ${ }^{-1}$. Only the middle two rows of each plot were harvested at the end of the growing season.

Sprinkler irrigation systems were used at Scottsbluff and Sidney, while furrow irrigation was used at Mitchell. Both NS and DS blocks were irrigated until flowering to ensure good plant establishment and early growth. Thereafter, stressed blocks were not irrigated. Plots were kept free from weeds and pests using a combination of hand labor and chemicals.

\section{Response Variables}

Environmental data, including daily rainfall $(\mathrm{mm})$ and minimum and maximum temperatures $\left({ }^{\circ} \mathrm{C}\right)$ were obtained from data recorded by automated weather stations near each research site and reported by the High Plains Regional Climate Center (http://www.hprcc.unl.edu) (Table 2).

To evaluate plant response to water stress, we determined yield $\left(\mathrm{kg} \mathrm{ha}^{-1}\right), 100$-seed weight $(\mathrm{g})$, and the number of days to flowering and maturity. To quantify drought severity, we calculated the drought intensity index (DII) (Fischer and Maurer, 1978); DII $=1-\mathrm{Xd} / \mathrm{Xp}$, where $\mathrm{Xd}$ is mean yield averaged across lines under DS, and $\mathrm{Xp}$ is mean yield averaged across lines under NS. Because of the difficulty of selecting for both improved performance under drought stress and high yield potential under NS conditions, it is advisable to utilize multiple indices when making selections (Schneider et al., 1997b; Abebe et al., 1998; Rosales-Serna et al., 2000). Therefore, we used the drought susceptibility index (DSI) and geometric mean (GM) to select drought-tolerant germplasm for further evaluation and inclusion in Nebraska's dry bean breeding program. The DSI is based on the change in yield under NS and DS environments; DSI $=(1-\mathrm{Yd} / \mathrm{Yp}) / \mathrm{DII}$ where Yd is mean yield of a line under DS and Yp is mean yield for the same line under NS (Fischer and Maurer, 1978). A small difference (low DSI value) suggests greater drought tolerance. However, this index does not differentiate between genotypes that perform well under both environments (e.g., tolerant of drought stress) and those that perform poorly under both environments (e.g., poorly adapted to the climate and/ or susceptible to other stressors such as insects or disease) (Schneider et al., 1997b; White and Singh, 1991; Clarke et al., 1992; Abebe et al.,
Table 2. Planting dates and the amount of rainfall, irrigation, and total water (irrigation + rainfall), and number of days with temperature above $35^{\circ} \mathrm{C}$ up to and after flowering in nonstressed (NS) and drought-stressed (DS) environments at three University of Nebraska research sites during 2006 and 2007.

\begin{tabular}{|c|c|c|c|c|c|}
\hline $\begin{array}{c}\text { Climate } \\
\text { variables }\end{array}$ & $\begin{array}{l}\text { Scottsbluff } \\
2006 \text { NS/DS }\end{array}$ & $\begin{array}{c}\text { Mitchell } \\
2006 \text { NS/DS }\end{array}$ & $\begin{array}{c}\text { Scottsbluff } \\
2007 \text { NS/DS }\end{array}$ & $\begin{array}{c}\text { Mitchell } \\
2007 \text { NS/DS }\end{array}$ & $\begin{array}{c}\text { Sidney } \\
2007 \text { NS/DS }\end{array}$ \\
\hline Planting dates & 24 May & 8 June & 31 May & 5 June & 1 June \\
\hline \multicolumn{6}{|l|}{ Rainfall, mm } \\
\hline Up to flowering & $104 / 104$ & $53 / 53$ & $23 / 23$ & $31 / 31$ & $46 / 46$ \\
\hline After flowering & $17 / 17$ & $56 / 56$ & $8 / 8$ & $22 / 22$ & $53 / 53$ \\
\hline \multicolumn{6}{|l|}{ Irrigation, mm } \\
\hline Up to flowering & $57 / 57$ & $63 / 63$ & $80 / 80$ & 190/190 & $76 / 76$ \\
\hline After flowering & $171 / 0$ & $127 / 0$ & $194 / 0$ & $190 / 0$ & $152 / 0$ \\
\hline Total water, mm & $349 / 178$ & 243/172 & $305 / 111$ & $433 / 243$ & $327 / 175$ \\
\hline Up to flowering & $161 / 161$ & $116 / 116$ & 103/103 & $221 / 221$ & $122 / 122$ \\
\hline After flowering & $188 / 17$ & $127 / 56$ & $202 / 8$ & $212 / 22$ & $205 / 53$ \\
\hline \multicolumn{6}{|l|}{$\begin{array}{l}\text { No. days max. } \\
\mathrm{T}>35^{\circ} \mathrm{C}^{\ddagger}\end{array}$} \\
\hline Up to flowering & 5 & 5 & 11 & 14 & 5 \\
\hline After flowering & 18 & 11 & 15 & 6 & 6 \\
\hline
\end{tabular}

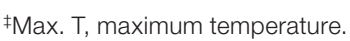

1998; Rosales-Serna et al., 2000). Furthermore, Rosielle and Hamblin (1981) suggest that selections based on DSI alone will lead to reduced productivity. Therefore, we also determined GM, an index based on performance under both DS and NS conditions; GM $=\sqrt{ }\left(Y_{S} \times Y i\right)$, where $Y_{s}$ is the mean seed yield of a line under DS and Yi is the mean yield of the line under NS (Schneider et al., 1997b).

\section{Statistical Analysis}

Data were analyzed using PROC MIXED (SAS Institute, 2004). As natural precipitation was part of our NS and DS treatments, soil water regime experienced by plants varied among locations and years. Therefore, each location-year combination was analyzed separately. Homogeneity of the variances was evaluated using Bartlett's $\chi^{2}$ test (Steel and Torrie, 1980). When appropriate the data were pooled. Location and replication were treated as random effects and water treatment (NS or DS) and genotypes were treated as fixed effects. In the pooled analyses, year $\times$ location and replication were random effects and water treatment and genotype were fixed effects. Means were separated using an F-protected LSD. All tests were considered significant at $P \leq 0.05$. 


\section{RESULTS AND DISCUSSION}

Although there was a significant interaction of genotype $\times$ environment $\times$ treatment (Table 3), data are reported and discussed across environments (Table 4). Most of the variance in Table 3 is attributed to genotypes rather than the respective interactions with other variables. The rank of top- and low-yielding lines did not change across environments.

Data from the 2006 trials at Sidney were excluded from analysis because of extensive hail damage before harvest. For the remaining trials, yield, 100-seed weight, and days to maturity differed $(P<0.01)$ with environment (each location-year combination), treatment, genotype, and their first-order interactions. Days to flowering

Table 3. Mean squares from the combined analysis of five environments, two treatments (nonstressed and drought stressed), and 10 genotypes evaluated at three University of Nebraska research sites near Scottsbluff, Mitchell, and Sidney, NE, during 2006 and 2007.

\begin{tabular}{|c|c|c|c|c|c|}
\hline \multirow[b]{2}{*}{ Source } & \multirow[b]{2}{*}{ df } & \multicolumn{4}{|c|}{ Mean square } \\
\hline & & Seed yield & $\begin{array}{c}100 \text {-seed } \\
\text { weight }\end{array}$ & $\begin{array}{l}\text { Days to } \\
\text { maturity }\end{array}$ & $\begin{array}{l}\text { Days to } \\
\text { flowering }\end{array}$ \\
\hline Environment (E) & 4 & $49,085,113 \cdot 2^{* *}$ & $551.6^{\star \star}$ & $1257.3^{\star *}$ & $358.8^{\star \star}$ \\
\hline Treatment $(\mathrm{T})$ & 1 & $347,435,247.3^{* *}$ & $2702.4^{\star *}$ & $2029.5^{\star}$ & 4.8 \\
\hline$E \times T$ & 4 & $7,815,543.6^{\star \star}$ & $65.8^{\star \star}$ & $223.9^{\star *}$ & 2.5 \\
\hline $\operatorname{Rep}(E \times T)$ & 30 & $417,115.5^{\star \star}$ & $3.2^{\star *}$ & $10.3^{\star *}$ & $3.4^{*}$ \\
\hline Genotypes (G) & 9 & $3,119,770.2^{\star \star}$ & $402.4^{\star \star}$ & $391.6^{\star \star}$ & $68.1^{\star \star}$ \\
\hline$E \times G$ & 36 & $279,262.9^{\star \star}$ & $14.4^{\star \star}$ & $25.8^{\star \star}$ & $7.5^{\star \star}$ \\
\hline$T \times G$ & 9 & $523,151.9^{\star \star}$ & $17.5^{\star \star}$ & $26.4^{\star \star}$ & 0.7 \\
\hline$E \times T \times G$ & 36 & $345,835.9^{\star \star \star}$ & $8.6^{\star \star}$ & $13.9^{\star \star}$ & 1.7 \\
\hline Error & 399 & $133,224.5$ & 1.4 & 4.8 & 2.0 \\
\hline
\end{tabular}

*Significant at $P<0.05$.

${ }^{\star *}$ Significant at $P<0.01$.

Table 4. Mean yield $\left(\mathrm{kg} \mathrm{ha}^{-1}\right)$, percent yield reduction (PR in \%) under droughtstressed (DS) relative to the nonstressed (NS) conditions, geometric mean (GM), drought susceptibility index (DSI), 100-seed weight (g), and days to maturity (days) for 10 genotypes evaluated at three University of Nebraska research sites near Scottsbluff, Mitchell, and Sidney, NE, during 2006 and 2007.

\begin{tabular}{|c|c|c|c|c|c|c|c|c|c|}
\hline \multirow[b]{2}{*}{ Genotype } & \multicolumn{2}{|c|}{ Yield } & \multirow[b]{2}{*}{ PR } & \multirow[b]{2}{*}{ GM } & \multirow[b]{2}{*}{ DSI } & \multicolumn{2}{|c|}{$\begin{array}{c}100 \text {-seed } \\
\text { weight }\end{array}$} & \multicolumn{2}{|c|}{$\begin{array}{l}\text { Days to } \\
\text { Maturity }\end{array}$} \\
\hline & NS & DS & & & & NS & DS & NS & DS \\
\hline & \multicolumn{2}{|c|}{$\mathrm{kg} \mathrm{ha}^{-1}$} & & & & 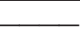 & 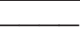 & 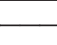 & 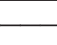 \\
\hline Beryl-R & 3564 & 1701 & 52 & 2462 & 0.9 & 28.5 & 22.4 & 83 & 78 \\
\hline Bill-Z & 3199 & 1587 & 50 & 2254 & 0.9 & 32.1 & 24.7 & 85 & 79 \\
\hline Matterhorn & 3440 & 1584 & 54 & 2335 & 0.9 & 32.3 & 27.3 & 85 & 79 \\
\hline SEC 10 & 2553 & 846 & 67 & 1470 & 1.2 & 29.7 & 24.4 & 87 & 86 \\
\hline SEN 3 & 3540 & 1326 & 63 & 2167 & 1.1 & 25.2 & 19.8 & 88 & 83 \\
\hline SEN 20 & 3195 & 1005 & 69 & 1792 & 1.2 & 23.3 & 19.0 & 89 & 86 \\
\hline SEN 21 & 3142 & 1092 & 65 & 1852 & 1.1 & 22.4 & 19.6 & 90 & 87 \\
\hline SER 10 & 3002 & 1320 & 56 & 1991 & 1.0 & 24.8 & 19.3 & 86 & 80 \\
\hline SER 22 & 3347 & 1773 & 47 & 2436 & 0.8 & 24.0 & 20.2 & 82 & 77 \\
\hline SER 26 & 3217 & 1325 & 59 & 2064 & 1.0 & 28.6 & 22.2 & 89 & 84 \\
\hline Overall mean & 3220 & 1356 & & & 1.0 & 27.1 & 21.9 & 86 & 82 \\
\hline $\operatorname{LSD}(0.05)^{\dagger}$ & \multicolumn{2}{|c|}{506} & & & & \multicolumn{2}{|c|}{1.7} & \multicolumn{2}{|c|}{3} \\
\hline CV \% & \multicolumn{2}{|c|}{15.9} & & & & \multicolumn{2}{|c|}{4.9} & \multicolumn{2}{|c|}{2.6} \\
\hline
\end{tabular}

tTo compare means among genotypes. differed $(P<0.01)$ with environment, genotypes, and

\section{Drought Stress}

During this study, drought stress was severe in 2006 (DII = 0.69 to 0.8 ) and moderate in 2007 (DII $=0.36$ to 0.64 ). Drought stress is considered severe at DII values above 0.7 (Ramirez-Vallejo and Kelly, 1998). Both the highest (DII = $0.8)$ and lowest $(\mathrm{DII}=0.36)$ levels of drought stress occurred at Mitchell. The highest drought stress (2006) occurred during a growing season with $11 \mathrm{~d}$ of temperatures above $35^{\circ} \mathrm{C}$ after flowering and relatively low levels of total water in both NS and DS blocks (Table 2). The lowest drought stress (2007) occurred during a growing season with relatively high levels of total water for both NS and DS plots, and few days with temperatures exceeding $35^{\circ} \mathrm{C}$ after flowering (Table 2). During 2007, plants in the DS plots at Mitchell remained healthy, which may have enabled them to more effectively utilize soil water and better maintain yield relative to plants in the NS plots.

\section{Yield}

Seed yield is the most reliable measure of drought tolerance in common bean (Ramirez-Vallejo and Kelly, 1998; White et al., 1994a). Yield was consistently lower for DS than for NS blocks across all locations and years. Drought stress reduced yield an average of $58 \%$ relative to NS conditions, ranging from 47 to $69 \%$ (Table 4). Other researchers have reported yield reductions ranging from 53 to $62 \%$ under drought stress (Terán and Singh, 2002a; Muñoz-Perea et al., 2006; Singh, 2007).

Comparing all environments, Scottsbluff in 2006 had the lowest yield under DS and NS because of relatively high incidence of common bacterial blight, a major seed-borne disease caused by the bacteria Xanthomonas axonapodis pv. phaseoli (Smith) Dye [syn. X. axanopodis pv. phaseoli (Smith) Vauterin et al.], and the brown pigmented variant $X$. axanopodis pv. phaseoli var. fuscans. Average common bacterial blight ratings ranged from 3.8 to 8.5 and 4.3 to 7.8 under NS and DS, respectively, on a scale where scores of 1 to 4 were considered resistant and 5 to 9 were considered susceptible (Schoonhoven and Pastor-Corrales, 1987). SER 26 had the lowest incidence of common bacterial blight (data not shown). Temperature 
may have also contributed to lower yields. Temperatures above $28^{\circ} \mathrm{C}$ cause excessive flower drop and abortion of fertilized ovules (Masaya and White, 1991; Rainey and Griffiths, 2005). The number of days with a maximum temperature above $35^{\circ} \mathrm{C}$ after flowering was greater at Scottsbluff in 2006 than for the other environments (Table 2).

Of the cultivars evaluated, SER 22 was one of the least affected by drought stress based on its low reduction in yield between NS and DS conditions (47\%) and its low DSI value (0.8) (Table 4). Bill-Z, Beryl$\mathrm{R}$, and Matterhorn also had relatively low yield reductions and DSI values (Table 4). Beryl-R and SER 22 were top performers under both moisture regimes with average yields of $3564 \mathrm{~kg} \mathrm{ha}^{-1}$ and $3347 \mathrm{~kg} \mathrm{ha}^{-1}$, respectively, under NS conditions and $1701 \mathrm{~kg} \mathrm{ha}^{-1}$ and $1773 \mathrm{~kg} \mathrm{ha}^{-1}$, respectively, under DS conditions. Geometric mean values also indicate that Beryl-R performed better under both environments followed by SER 22, Matterhorn, and Bill-Z (Table 4). To further explore how each line performed, we plotted seed yield under DS conditions against seed yield under NS conditions (Fig. 1). Once again, SER 22, Beryl-R, and Matterhorn performed best under both conditions across all environments (Fig. 1). This was also true for Beryl-R and Matterhorn for each individual environment and for SER 22 in four of the five environments (data not shown). The exception was at Sidney 2007, when SER 22 performed well under DS but below average under NS conditions. Overall, Bill-Z performed well under DS conditions, but slightly below average under NS conditions (Fig. 1).

In contrast, SEC 10 and SEN 21 were most affected by drought stress based on mean yield reduction (67 and 69\%, respectively) and DSI value (Table 4). SEN 20 and SEN 3 also had relatively high DSI values (Table 4). SEC 10 had the lowest yield under both conditions and the lowest GM value and was the worst performer across all environments (Table 4 and Fig. 1). SEN 20, SEN 21, and SEN 3 responded inconsistently to the different environments (data not shown), and overall did not perform well enough to be considered for use in our bean breeding program (Table 4 and Fig. 1). Although these lines were improved for drought tolerance, they may not be adapted to western Nebraska.

SER 22, Beryl-R, and Matterhorn show the most promise as sources of drought tolerance. Lines derived from Mesoamerica $\times$ Durango exhibit higher levels of drought tolerance (Terán and Singh, 2002a), and SER 22, from the Mesoamerican gene pool, shows potential for use in such crosses. Although Matterhorn performed well under both water regimes in this study, others reported high yields under DS conditions but only moderate yields under NS conditions (Muñoz-Perea et al., 2006; Singh, 2007). Bill-Z showed promise because of its strong performance under DS conditions. However, yields were somewhat variable and more moderate under NS conditions. In contrast, Singh (2007) reported high yields for Bill-Z under both water regimes and Muñoz-Perea et al. (2006) reported that Bill-Z was the highest yielding pinto line under NS conditions.

\section{Seed Quality}

Drought stress reduced 100-seed weight an average of $19.2 \%$, ranging from $12.5 \%$ for SEN 21 to $23.1 \%$ for Bill-Z (Table 4). Similar results were reported by Terán and Singh (2002a) and Singh (2007) (13 and 14\%, respectively).

Of the most promising genotypes based on yield response, SER 22 (15.8\%) and Matterhorn (15.5\%) had relatively low reductions in 100 -seed weight (Table 4), and Beryl-R was intermediate (21.4\%). Bill-Z (23.1\%) had the greatest 100 -seed weight reduction.

\section{Phenology}

Days to flowering was not affected by the NS and DS treatments $(P>0.05)$, because both treatments experienced the same moisture regime until flowering. Across all environments, the average days to flowering were $47 \mathrm{~d}$ (data not shown). Within each genotype, flowering occurred within $2 \mathrm{~d}$ of each other.

Under terminal stress, number of days to maturity is often shortened. In this study, beans matured an average of $4 \mathrm{~d}$ earlier under DS conditions than under NS conditions (Table 4). Similar results were reported by Terán and Singh (2002a, 2002b). The greatest difference was observed for Bill Z (Scottsbluff 2007) when plants in the 
DS block matured $13 \mathrm{~d}$ earlier than those in the NS blocks (data not shown).

\section{CONCLUSIONS}

The Mesoamerican line SER 22 and cultivars Beryl-R and Matterhorn are recommended as sources of drought tolerance based on their high yield under DS and high GM values.

\section{Acknowledgments}

Financial support from the Nebraska Dry Bean Commission (Project no. WBS 26-6243-0206-001), 2005 and 2006, and the Burlington Northern Endowment (Project no. WBS 27-62410074-001), 2006, is highly appreciated. We also appreciate the technical support of Rob Higgins, Dave Reichert, and DongMan Khu, and statistical support from Henry Terán and Fredy Salazar. Germplasm provided by Dr. Steve Beebe from CIAT and seed increased in 2005 by Dr. Timothy Porch, TARSUSDA, PR, is highly appreciated.

\section{References}

Abebe, A., M.A. Brick, and R.A. Kirkby. 1998. Comparison of selection indices to identify productive dry bean lines under diverse environmental conditions. Field Crops Res. 58:15-23.

Acosta-Gallegos, J.A., and M.W. Adams. 1991. Plant traits and yield stability of dry bean (Phaseolus vulgaris) cultivars under drought stress. J. Agric. Sci. 117:213-219.

Acosta-Gallegos, J.A., and J.W. White. 1995. Phenological plasticity as an adaptation by common bean to rainfed environments. Crop Sci. 35:199-204.

Census of Agriculture. 1992. Farm and ranch irrigation survey. USDA, Washington, DC.

Census of Agriculture. 1997. Farm and ranch irrigation survey. USDA, Washington, DC.

Census of Agriculture. 2002. Farm and ranch irrigation survey. USDA, Washington, DC.

Clarke, J.M., R.M. DePauw, and T.F. Townley-Smith. 1992. Evaluation of methods for quantification of drought tolerance in wheat. Crop Sci. 32:723-728.

FAOSTAT. 2006. FAO statistical databases and data sets. Available at faostat.fao.org/ (verified 4 Aug. 2009). FAO, Rome.

Fischer, R.A., and R. Maurer. 1978. Drought resistance in spring wheat cultivars: I. Grain yield responses. Aust. J. Agric. Res. 29:897-912.

Kelly, J.D., G.L. Hosfield, G.V. Varner, M.A. Uebersax, and J. Taylor. 1999. Registration of 'Matterhorn' great northern bean. Crop Sci. 39:588-589.

Lema, M., H. Terán, M. Dennis, C. Robinson, and S.P. Singh. 2006. Drought resistance in different market classes of dry bean. Annu. Rep. Bean Improv. Coop. 49:241-242.

Muñoz-Perea, C.G., H. Terán, R.G. Allen, J.L. Wright, D.T. Westermann, and S.P. Singh. 2006. Selection for drought resistance in dry bean landraces and cultivars. Crop Sci. 46:2111-2120.

Rainey, K.M., and P.D. Griffiths. 2005. Differential response of common bean genotypes to high temperature. J. Am. Soc. Hortic. Sci. 130:18-23.

Ramirez-Vallejo, P., and J.D. Kelly. 1998. Traits related to drought resistance in common bean. Euphytica 99:127-136.

Rosales-Serna, R., P. Ramírez-Vallejo, J.A. Acosta-Gallegos, F. Castillo-González, and J.D. Kelly. 2000. Grain yield and drought tolerance of common bean under field conditions. Agrociencia 34:153-165.

Rosielle, A.A., and J. Hamblin. 1981. Theoretical aspects of selection for yield in stress and non-stress environments. Crop Sci. 21:943-946.

SAS Institute. 2004. User's guide: Statistics. SAS Inst., Cary, NC.

Schneider, K.A., M.E. Brothers, and J.D. Kelly. 1997a. Markerassisted selection to improve drought resistance in common bean. Crop Sci. 37:51-60.

Schneider, K.A., R. Rosales-Serna, F. Ibarra-Perez, B. CazaresEnriquez, J.A. Acosta-Gallegos, P. Ramirez-Vallejo, N. Wassimi, and J.D. Kelly. 1997b. Improving common bean performance under drought stress. Crop Sci. 37:43-50.

Selley, R.A., T. Barret, and R.N. Klein. 2004. Nebraska crop budgets, 2004. Circular EC04-872-S. Univ. of Nebraska, Coop. Ext., Lincoln.

Shenkut, A.A., and M.A. Brick. 2003. Traits associated with dry edible bean (Phaseolus vulgaris L.) productivity under diverse soil moisture environments. Euphytica 133:339-347.

Singh, S.P. 1995. Selection for water-stress tolerance in interracial populations of common bean. Crop Sci. 35:118-124.

Singh, S.P. 2001. Broadening the genetic base of common bean cultivars. Crop Sci. 41:1659-1675.

Singh, S.P. 2007. Drought resistance in the race Durango dry bean landraces and cultivars. Agron. J. 99:1219-1225.

Steel, R.G.D., and J.H. Torrie. 1980. Principles and procedures of statistics. A biometrical approach. McGraw-Hill, New York.

Terán, H., and S.P. Singh. 2002a. Comparison of sources and lines selected for drought resistance in common bean. Crop Sci. 42:64-70.

Terán, H., and S.P. Singh. 2002b. Selection for drought resistance in early generations of common bean population. Can. J. Plant Sci. 82:493-497.

USDA-ERS. 2008. Dry edible beans. In Vegetable and melons outlook/VGS-330/December 16, 2008. Available at www. ers.usda.gov/Briefing/DryBeans/PDFs/DBnOutlook.pdf (verified 3 Aug. 2009). USDA-ERS, Washington, DC.

van Schoonhoven, A., and M.A. Pastor-Corrales. 1987. CIAT. Standard evaluation of bean germplasm. Centro Internacional de Agricultura Tropical (CIAT), Cali, Colombia.

White, J.W., J.A. Castillo, J.R. Ehleringer, J.A.C. Garcia, and S.P. Singh. 1994a. Relations of carbon isotope discrimination and other physiological traits to yield in common bean (Phaseolus vulgaris) under rainfed conditions. J. Agric. Sci. 122:275-284.

White, J.W., M. Ochoa, P. Ibarra, and S.P. Singh. 1994b. Inheritance of seed yield, maturity and seed weight of common bean (Phaseolus vulgaris) under semi-arid rainfed conditions. J. Agric. Sci. 122:265-273.

White, J.W., and S.P. Singh. 1991. Breeding for adaptation to drought. p. 501-560. In A. van Schoonhoven and O. Voysest (ed.) Common beans, research and crop improvement. CAB Int., CIAT, Colombia.

Wood, D.R., M. Ballarin, H.F. Schwartz, M.A. Brick, and C.H. Pearson. 1989. Registration of 'Bill-Z' pinto bean. Crop Sci. 29:488.

Yonts, C.D. 2005. Water supply: What a difference a year makes. Irrigator's News Line 9(2). 